\title{
SOME FACTORS AFFECTING TEST-DAY VISUAL MILK SOMATIC CELL CONCENTRATION AND MILK YIELD IN HOLSTEIN FRIESIAN COWS RAISED IN EGYPT
}

\author{
S. A. Mokhtar, A. A. Amin and A. Ghazy \\ Department of Animal Production, Faculty of Agriculture, Suez Canal University, \\ Ismailia, Egypt
}

\section{SUMMARY}

To assess the relationship between sample test-day milk yield (TDM) and milk somatic cell concentration of Holstein Friesian cows raised under Egyptian conditions, the effects of cow source, farm, season and year of calving, parity and age at calving were investigated. Data on a total number of 2811 cows were collected from four dairy farms located in different areas (Al-Salhia and Dunia in Ismailia region, and Delta Misr farm 1 and 2 in Monofia governorate). Milk somatic cell concentration was examined using visualized linear score $\left(V L S_{S C C}\right)$ ranging from 0 to 3 digits. $V L S_{S C C}$ was converted to expected somatic cell count $\left(E_{S C C}\right)$, which in turn was expressed as expected somatic cell score $\left(E_{S C S}\right)$ in statistical analysis.

The results showed that the direct animal random effect was responsible for a remarkable variability in TDM and partially for $E_{S C S}$. These findings refer to the presence of genetic variability of these traits and indicate the possibility of genetic improvement of general udder health and milk yield through appropriate genetic improvement strategies. Overall least square means (LSM) of TDM and $E_{S C C}$ ranged from 10.1 to $27.9 \mathrm{Kg} /$ day and from 575,000 to 1,404,000 cells per ml milk, respectively. The highest $L S M_{T D M}$ was $21.7+4.47 \mathrm{Kg} /$ day at the third parity. Estimates of LSM for $E_{S C C}$ ranged from 575,000 to 957,000 and 851,000 to 1,404,000 cells per $\mathrm{ml}$ milk for the two groups representing low and high level of $E_{S C C}$, respectively. Age at calving and parity are generally the second most affecting factor on TDM and $E_{S C S}$. Changes in TDM and $E_{S C C}$ were computed at different levels of $V L S_{S C C}$. In general, TDM decreased with advancing level of $E_{S C C}$ indicating a negative relationship. The average overall reduction in TDM was $4.01 \mathrm{Kg} /$ day and the corresponding increase of $E_{S C C}$ was 418,670 cells per ml milk. Prediction of milk SCC was based on daily milk yield $\left(D Y_{K g}\right)$, days in milk (DIM days $)$ and order of lactation (Pr).

The general form is: milk SCC $=2119-59.94 * D Y-9.56 * D I M-19.43 * P r$.

The equation could be used for prediction under the prevailing conditions of local Holstein Friesian dairy farms. Accuracies of all suggested SCC prediction equations ranged from $57.4 \%$ to $84.8 \%$.

Keywords: Somatic cell count, test-day milk yield, Holstein Friesian, stage of lactation.

Issued by The Egyptian Society of Animal Production 


\section{INTRODUCTION}

Mastitis is one of the most costly health problems of dairy cattle and is a major source of economic loss to dairy farmers. It results in a significant reduction in milk yield, due mainly to damage of milk-producing tissues in the udder. There is, also, a reduction in butterfat and casein levels, resulting in poorer cheese making properties. Mastitis is also the most frequent disease responsible for early culling of milking cows. The somatic cell count is the number of cells present in milk (body cells as distinguished from invading bacterial cells). It is used as an indicator of udder infection. Roger and Peter (1995) indicated that a herd with a somatic cell count (SCC) of about $200000 / \mathrm{ml}$ will have minimal losses in yield, but for every increase in cell count of $100000 / \mathrm{ml}$, there will be a reduction of $2.5 \%$ in milk yield. Miller (1984) indicated that mastitis causes a yearly loss exceeding two billion Dollars to commercial dairy farmers in the USA, mainly due to reduced milk yield from infected cows. This high level of losses has raised interest in breeding as means of reducing the incidence of mastitis by supplementing management control programs. Mrode and Swanson (1996) showed a negative relationship between production and SCC in later parities due partly to culling in the first parity on the basis of mastitis and milk production. Culling practices would remove low milk producers and potentially high producers with mastitis infection and high SCC; thus high milk producers, with low SCC, would be favored to have a second parity. Seasonal effect on SCC was reported by many workers (Schutz et al., 1994 and Zhang et al., 1994). They concluded that the highest SCC occurred during summer months. The objectives of the present study were: 1) to study the effect of farm, season and year of calving, parity, age at calving and stage of lactation, on test-day milk (TDM) and visualized linear score $\left(\mathrm{VLS}_{\mathrm{SCC}}\right)$ and 2 ) to asses the relationship between the two variables.

\section{MATERIALS AND METHODS}

\section{Structure of the data:}

Productive data of Holstein Friesian cows were collected from four farms. The total number of dairy cows used in the present study was 723, 737, 1061, and 290 in Al-Salhia, Dunia, and Delta Misr farm number 1 and number 2, respectively. The data were composed of 3909 test-day records of producing cows in the first four parities. The first measurement on the cow was obtained three weeks after parturition. Information on dates of first calving, parity, source of the cow (imported as pregnant heifer or locally born in Egypt), calving date, dates of all available testday observations and date of drying off were recorded for all animals. Stage of lactation was divided into four groups (lactational quarter year: LQY) going from the first month of lactation up to the $12^{\text {th }}$ month with three months interval each (Table 1). Determination of milk somatic cell was performed after Gary (1985). The most important materials used in the test were smooth black bakelite sheets, $\mathrm{NaOH} \mathrm{4 \%}$;, medicine droppers, mixer sticks "15cm long" and picture guide for scoring test reactions. All samples were stored at 0 to $4^{\circ} \mathrm{C}$. Testing must be completed within 36 $\mathrm{hr}$ after collection. Levels of SCC in milk were presented as Visualize Linear Score 
of somatic cell count $\left(\mathrm{VLS}_{\mathrm{SCC}}\right.$ ) using 0-3digits (Table 2). $\mathrm{VLS}_{\mathrm{SCC}}$ was converted to expected somatic cell count $\left(\mathrm{E}_{\mathrm{SCC}}\right)$ according to Barillet et al. (1984). For statistical analysis $\mathrm{E}_{\mathrm{SCC}}$ was further expressed as expected somatic cell score $\left(\mathrm{E}_{\mathrm{SCS}}\right)$ using $\log _{2}$ $\mathrm{E}_{\mathrm{SCC}}$ (Rogers et al., 1991). Data were analyzed using Multitrait Derivative Free Restricted Maximum Likelihood (MTDFREML) animal model (Boldman et al., 1997). The general linear animal mixed model in matrix notation is given by

$y=X b+Z_{1} a+Z_{2} c+e$.

Where: $y$ is the vector of observations, $X$ is the known matrix, $b$ is the vector of fixed effects (four parities and/or age at calving (16 age groups, Table 1), cow source (imported and local), four dairy farms (Al-Salhia, Dunia, and Delta Misr farm number 1 and number 2,), four season of calving and three year of calving from 1999 to 2001), $Z_{1}, Z_{2}$ are the known incidence matrices, $a$, and $c$ are non-observable sire and cow random vectors, respectively. Expectation and variances are defined as:

$E\left[\begin{array}{l}a \\ c \\ e\end{array}\right]=\left[\begin{array}{l}0 \\ 0 \\ 0\end{array}\right] \quad \operatorname{var}\left[\begin{array}{l}a \\ c \\ e\end{array}\right]=\left[\begin{array}{cc}A \sigma_{a}^{2} & \sigma_{a u} \ldots \ldots \ldots \ldots . . .0 .0 \\ \sigma_{a u} & B \sigma_{c}^{2} \ldots \ldots . . I \sigma^{2} e_{1} \\ 0 & I \sigma^{2} e_{1} \ldots \ldots I \sigma^{2} e_{2}\end{array}\right]$

Where: $A$ and $B$ are the numerator relationship matrix among animals of sire and cow within sire, $\mathrm{I}$ is the identity matrix, $\sigma^{2} a$ and $\sigma^{2}{ }_{c}$ are the direct random additive genetic effect of the sire and cow. $\sigma^{2} e_{1}$ and $\sigma^{2} e_{2}$ are the sire and cow population error variance.

Table 1. Number (Obs) and percentage (Obs\%) of test-day observation according to calving age (CA,mo) within parity (Pr) and lactational quarter year (LQY, mo.)

\begin{tabular}{c|c|c|c|c|c|c|c|c}
\hline \multirow{4}{*}{ Parity } & \multicolumn{7}{|c|}{ CA / parity } & \multicolumn{3}{c}{ LQY } \\
\cline { 2 - 9 } & CA & Obs & Obs\% & Obs & Obs\% & LQY & Obs & Obs\% \\
\hline \multirow{4}{*}{$1^{\text {st }}$} & $\leq 24$ & 203 & 11.25 & & & & & \\
& $>24-$ & 961 & 53.27 & 1804 & 46.15 & $1-3$ & 915 & 23.41 \\
& $>28$ & 640 & 35.48 & & & & & \\
$2^{\text {nd }}$ & $\leq 36$ & 211 & 21.44 & & & & 131 & 33.67 \\
& $>36-$ & 512 & 52.03 & 984 & 25.17 & $4-6$ & 6 & \\
& $>40$ & 261 & 26.52 & & & & & \\
$3^{\text {rd }}$ & $\leq 48$ & 161 & 20.02 & & & & 110 & 28.29 \\
& $>48-$ & 531 & 66.04 & 804 & 20.57 & $7-9$ & 6 & \\
& $>52$ & 112 & 13.93 & & & & & \\
$4^{\text {th }}$ & $\leq 60$ & 103 & 32.49 & & & & & \\
& $>60-$ & 131 & 41.32 & 317 & 8.11 & $10-12$ & 572 & 14.63 \\
& $>64$ & 83 & 26.18 & & & & & \\
\hline
\end{tabular}


Table 2. Visual linear score $\left(\mathrm{VLS}_{\mathrm{SCC}}\right)$ of milk somatic cell $\left(10^{3} / \mathrm{ml} \mathrm{milk)}\right.$ and midpoint (MP) values in milk samples (Gary, 1985)

\begin{tabular}{lccc}
\hline \multicolumn{1}{c}{ Result test } & VLS $_{\mathrm{SCC}}$ & Range*10 $^{3}$ & $\mathrm{MP}$ \\
\hline $\begin{array}{l}\text { Mixture is opaque and milky in appearance, and } \\
\text { entirely free from precipitate. }\end{array}$ & 0 & $\leq 500$ & 250 \\
$\begin{array}{l}\text { Background is less opaque but still somewhat milky } \\
\text { Background is slightly watery in appearance. }\end{array}$ & 1 & $>500-\leq 1000$ & 750 \\
$\begin{array}{l}\text { Background is definitely watery, with larger clumps } \\
\text { of coagulated material. }\end{array}$ & 3 & $>1000-\leq 1500$ & 1250 \\
\hline
\end{tabular}

\section{RESULTS AND DISCUSSION}

\section{Least-Square analysis of variance:}

Results of analysis of variance for TDM and $\mathrm{E}_{\mathrm{SCS}}$ are presented in Table 3. Among all investigated factors, animal random effect was the most affecting factor on TDM where it showed the highest mean square value (Table 3). Effect of animal on TDM across and within parities was proved to be significant $(\mathrm{P} \leq 0.01)$. These results are in agreement with Mohamed (1998) and refer to the presence of genetic variability of this trait, indicating the possibility of genetic improvement of milk yield through proper genetic improvement strategy.

Table 3. Mean-square values of test-day milk yield (TDM) and expected somatic cell score $\left(E_{S C S}\right)$ within and across parities

\begin{tabular}{|c|c|c|c|c|c|c|c|c|c|c|}
\hline \multirow{3}{*}{ Source } & \multirow{3}{*}{$\mathrm{df}$} & \multirow{3}{*}{ Overall } & \multicolumn{4}{|c|}{ TDM } & \multirow{3}{*}{ Overall } & \multicolumn{3}{|c|}{$\mathrm{E}_{\mathrm{SCS}}$} \\
\hline & & & \multicolumn{4}{|c|}{ Parities } & & \multicolumn{3}{|c|}{ Parities } \\
\hline & & & $1^{\text {st }}$ & $2^{\text {nd }}$ & $3^{\text {rd }}$ & $4^{\text {th }}$ & & $1^{\text {st }}$ & $2^{\text {nd }}$ & $3^{\text {rd }}$ \\
\hline Animal R.E. & 1176 & $70.39^{* * * *}$ & $49.70^{* * *}$ & $60.49^{* * *}$ & $46.84^{* *}$ & $50.62^{* * *}$ & 0.18 & 0.11 & $0.37^{* * *}$ & 0.39 \\
\hline Cow source & 1 & $33.08^{*}$ & $23.98^{*}$ & 21.15 & 11.31 & $22.07^{*}$ & 0.11 & 0.05 & $0.19^{*}$ & 0.22 \\
\hline Farm & 3 & $50.17^{* *}$ & $26.08^{*}$ & 24.74 & $40.91^{* *}$ & $36.18^{* * *}$ & 0.18 & 0.07 & $0.30^{* *}$ & 0.35 \\
\hline Season & 3 & $37.92^{*}$ & $27.32^{*}$ & $36.61^{*}$ & 22.57 & 20.85 & 0.00 & 0.06 & $0.24^{*}$ & 0.33 \\
\hline Year & 2 & $41.89^{* *}$ & 18.86 & $33.67^{*}$ & 22.65 & 17.24 & 0.14 & 0.04 & $0.28^{* *}$ & 0.26 \\
\hline Parity & 3 & $66.33^{* *}$ & & & & & $0.37^{* * *}$ & & & \\
\hline Calving Age & & & $46.46^{* * *}$ & 32.54 & $39.72^{* *}$ & $41.64^{* * *}$ & & $0.15^{*}$ & $0.67^{* * *}$ & $0.70^{* *}$ \\
\hline Cov: $\mathrm{Stg}_{\text {linear }}$ & 1 & $41.04^{* *}$ & $23.41^{*}$ & 25.52 & $27.71^{*}$ & $31.43^{* *}$ & $0.28^{* *}$ & 0.11 & $0.43^{* *}$ & $1.01^{* * * *}$ \\
\hline Stg Quadratic & 1 & $32.96^{*}$ & 19.63 & 25.70 & $30.68^{*}$ & $27.79^{*}$ & $0.19^{*}$ & 0.07 & $0.25^{*}$ & 0.43 \\
\hline Ran. Res. & 2708 & 32.15 & 21.53 & 37.00 & 28.19 & 23.61 & 0.19 & 0.15 & 0.16 & 0.58 \\
\hline Res. df & & & 849 & 616 & 417 & 84 & 2369 & 842 & 609 & 410 \\
\hline $\mathrm{R}^{2} \%$ & & 92.08 & 91.62 & 87.56 & 89.58 & 91.3 & 89.45 & 80.85 & 94.32 & 86.47 \\
\hline $\begin{array}{l}\text { Animal R.E. } \\
\text { Cov.: Covaria } \\
\text { lactation }\end{array}$ & : Anim & al Randon & Effect & & & & & & & \\
\hline
\end{tabular}

Analysis of variance for pooled data set (Table 3) showed that animal random effect was not significant on $\mathrm{E}_{\mathrm{SCS}}$. However, the magnitude of mean square of $\mathrm{E}_{\mathrm{SCS}}$ due to animal effect within parity increased from the first to the third parity. It was 
proved to be significant only in the second parity. The present results agree with those reported by Emanuelson and Philipson (1984) and disagree with those reported by Mohamed (1998).

Results in Table 3 show that differences between farms in TDM were significant $(\mathrm{P}<0.01)$ either for the pooled data or the separate parities except the second parity. These results are in accordance with those of many investigators working on different breeds of dairy cattle (Afifi et al., 1992 and Amin, 1998). In general, variation in TDM among farms could be attributed to different feeding and managerial practices and due to the differences in genetic make-up of the stock. Differences among farms in $\mathrm{E}_{\mathrm{SCS}}$ were significant $(\mathrm{P}<0.05)$ across parities and within the second parity $(\mathrm{P}<0.01)$ (Table 3). Significant differences among herds in milk somatic cell concentration could be attributed to application of different control programs tend to provide hygienic and management practices to control intra-mammary infection.

Season and year of calving affected significantly $(\mathrm{P}<0.05$ or $\mathrm{P}<0.01)$ TDM of the pooled data (Table 3). Similarly, the study of Afifi et al. (1992) revealed significant differences in milk yield due to season and year of calving. Season and year of calving generally had non-significant effect on $\mathrm{E}_{\mathrm{SCS}}$ (Table 3). Liebe et al. (1996) reported non-significant effect of season and year of calving on milk somatic cell count. However, significant effect of season on milk somatic cell was reported by Rodriguez et al. (2000). The reasons for seasonal variations are unknown and only speculated to be the effects of housing and temperature changes on infection status.

Parity and age at calving are generally the second most affecting factors on TDM and $\mathrm{E}_{\mathrm{SCS}}$ as shown in Table 3. Age could be expected to be very important source of variation if the heifers were inseminated for first time so early in their life that some of them had not yet reached physiological maturity and consequently body size and their body systems are still at lower levels.

Overall mean square of TDM due to stage of lactation was higher than that within parity (Table 3). Mean square of TDM caused by the linear covariate term of stage of lactation increased markedly with advancing parity. Across parities, and within the $2^{\text {nd }}$ and $3^{\text {rd }}$ parity stage of lactation affected significantly $E_{S C S}$ mainly through its linear covariate term. The effect of stage of lactation on somatic cell score has been proved to be significant in the study of Rupp et al. (2000). Farghaly (2002) showed that stage of lactation affected significantly milk somatic cell, since both the original and logarithm milk somatic cell were the highest shortly after calving, dropped to a minimum between 40 and 80 days postpartum and then steadily increased until the end of lactation.

\section{Least-squares means:}

Estimates of least-squares means (LSM) of TDM with their standard errors in the first four parities, calving seasons and farms are presented in Table 4. Overall mean of test-day milk yield was $17.5 \pm 5.2 \mathrm{~kg}$. Results in Table 4 show that TDM increased gradually from the first lactation till the third one and decreased thereafter. The present results agree with those reported by Soliman and Khalil (1993), and Afifi et al. (1992) who found that means and standard deviations of milk yield increased with the advance of parity. They also reported much greater rise in yield from first to second parity than with any other two parities. Mohamed (1998) showed that milk yield increased with advancing age and reached its peak at the fourth parity. 
Table 4. Least-squares means (LSM $\left.{ }_{\mathrm{Kg}}+\mathrm{SE}\right)$ for test-day milk yield (TDM) in the first four parities, calving season and farms

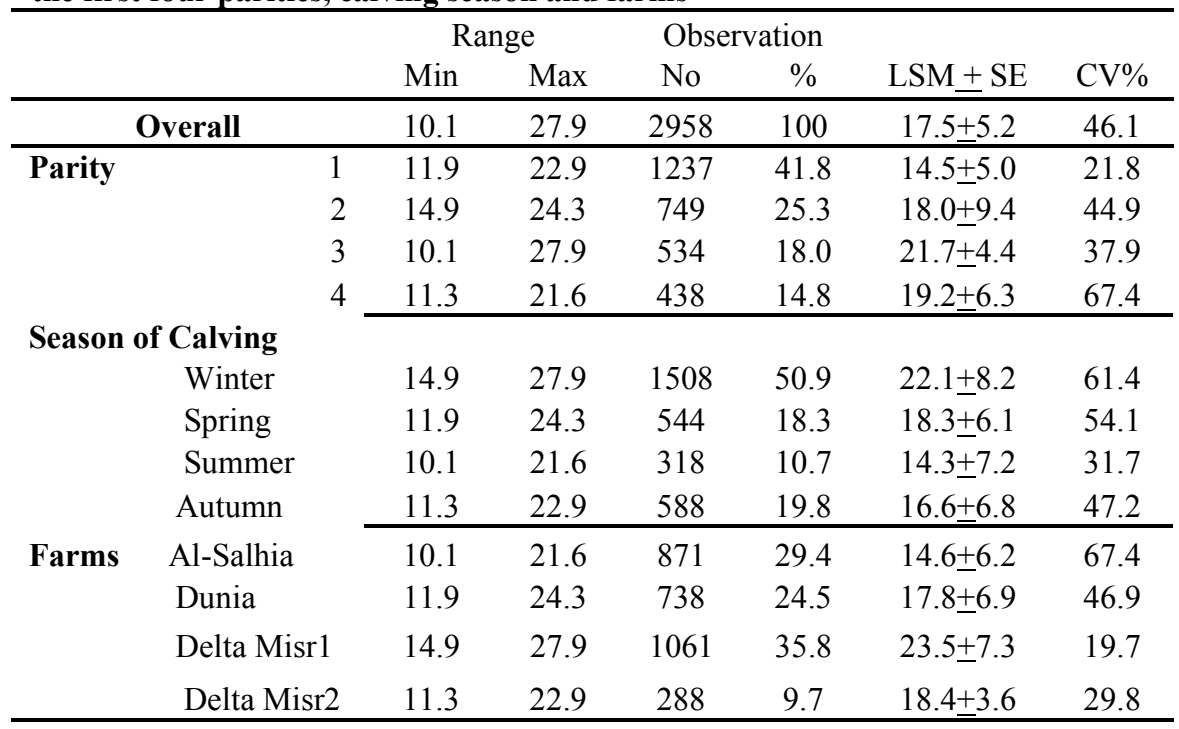

$\mathrm{CV}$ : Coefficient of variability

Winter calvers produced the highest TDM followed by spring calvers (Table 4). Cows calved in summer produced the lowest TDM as expected due to the unfavorable surrounding high environmental temperature along with the low quality of feed and the low feed intake. Similar results were obtained by Soliman and Khalil, (1993), who showed that milk yield and constituents, in general, were highest in autumn and winter calvings, while heifers and cows calving in summer months gave the lowest milk yield.

Results in Table 4 indicate that cows of Delta Misr farm1 produced the highest TDM followed by those of Delta Misr farm 2 while the lowest TDM was recorded by cows of Al-Salhia farm. Differences in performance among herds may reflect genetic back-ground and managerial practices be adopted in these herds. Moreover, in AlSalhia farm, no selection for milk yield has been exercised in the last 15 years. Cows of this herd had been frequently subjected to a substantial fluctuation in concentrates available. These unfavorable conditions along with the possible inevitable inbreeding might result in such low level of production.

Changes of SCC and TDM across stage of lactation within parity:

Two groups were formed according to level of SCC in milk i.e. $\mathrm{LE}_{\mathrm{SCC}}\left(\leq 750^{*} 10^{3}\right.$ cell $/ \mathrm{ml})$ and $\mathrm{HE}_{\mathrm{SCC}}\left(>750 * 10^{3}\right.$ cell $\left./ \mathrm{ml}\right)$. This analysis was performed for the whole data as well as within parity. Least-squares means (LSM) of somatic cell count $\left(\mathrm{E}_{\mathrm{SCC}} * 10^{3}\right) / \mathrm{ml}$ of milk and TDM classified into lactational quarter year (LQY) classes within parity for low and high $\mathrm{E}_{\mathrm{SCC}}$ are given in Table 5. The results indicated clearly that $\mathrm{E}_{\mathrm{SCC}}$ increased progressively with advancing month of lactation up to the fourth quarter of year (10-12 mo) after calving. This trend is observable for all parities 
whether within the group with low $\mathrm{E}_{\mathrm{SCC}}$ or the other group with high $\mathrm{E}_{\mathrm{SCC}}$. Similar results were given by Schutz et al. (1994) who observed that the curves of somatic cell count (first and later lactation) in Holstein cattle were decreased to the nadir during the first 90 days postpartum and increased steadily during the remainder course of lactation. Mohamed (1998) reported that the peak of SCC in milk was attained at the second month of lactation, decreased to its lowest level at the third month and increased through the fourth month of lactation. He attributed the high SCC at the beginning of lactation to excessive shedding of epithelial cells in a small amount of milk produced as the mammary gland resumes her function after a dormant period, and at the end of lactation due to the high concentration of cells in a small amount of milk yield as milk production decline (dilution effect).

Table 5. Least-squares means of expected somatic cell count $\left(\mathrm{E}_{\mathrm{SCC}} * 10^{3} / \mathrm{ml} \mathrm{milk}\right)$ and test-day milk yield (TDM) classified into lactational quarter year across parity for low and high $\mathrm{E}_{\mathrm{SCC}}$ group

\begin{tabular}{|c|c|c|c|c|c|c|c|c|}
\hline \multirow{3}{*}{$\begin{array}{l}\text { Traits/ } \\
\text { Parity }\end{array}$} & \multicolumn{4}{|c|}{ Low somatic cell concentration $\left(\mathbf{L E}_{\mathrm{SCC}}\right)$} & \multicolumn{4}{|c|}{ High somatic cell concentration $\left(\mathrm{HE}_{\mathrm{SCC}}\right)$} \\
\hline & \multicolumn{8}{|c|}{ Lactational Quarter Year ( months) } \\
\hline & 1-3 & $4-6$ & $7-9$ & 10-12 & $1-3$ & 4-6 & $7-9$ & 10-12 \\
\hline $\mathrm{E}_{\mathrm{SCC}}$ all & $575+13$ & $535+24$ & $861+52$ & $957+73$ & $851+102$ & $986+129$ & $1127+142$ & $1404+261$ \\
\hline $1^{\text {st }}$ & $297+8$ & $491+14$ & $715+19$ & $823+24$ & $833+94$ & $712+88$ & $964+57$ & $1115+120$ \\
\hline $2^{\text {nd }}$ & $328+11$ & $497+13$ & $849+21$ & $925+42$ & $842+101$ & $873+91$ & $1023+98$ & $1326+131$ \\
\hline $3^{\text {rd }}$ & $364+14$ & $541+25$ & $867+37$ & $963+58$ & $859+97$ & $994+109$ & $1167+132$ & $1451+124$ \\
\hline $4^{\text {th }}$ & $385+11$ & $564+17$ & $841+39$ & $991+121$ & $860+106$ & $985+110$ & $1181+84$ & $1449+111$ \\
\hline $\begin{array}{l}\text { TDM } \\
\text { all }\end{array}$ & $\begin{array}{r}12.2+2 . \\
1\end{array}$ & $18.7+3.5$ & $27.4+4.2$ & $19.15+4.6$ & $9.7+3.8$ & $13.3+5.7$ & $19.6+6.3$ & $11.6+6.4$ \\
\hline $1^{\text {st }}$ & $\begin{array}{r}10.3+1 . \\
5\end{array}$ & $17.3+4.3$ & $22.9+5.2$ & $18.15+4.1$ & $4.2+2.3$ & $10.6+7.9$ & $17.5+8.3$ & $8.1+3.6$ \\
\hline $2^{\text {nd }}$ & $\begin{array}{r}10.9+2 . \\
0\end{array}$ & $18.0+5.0$ & $26.4+5.3$ & $18.73+5.4$ & $7.7+2.6$ & $12.8+4.7$ & $20.6+5.6$ & $12.4+6.3$ \\
\hline $3^{\text {rd }}$ & $\begin{array}{r}13.8+2 . \\
5\end{array}$ & $21.6+5.1$ & $36.3+6.1$ & $23.61+5.3$ & $11.7+1.5$ & $15.7+5.7$ & $18.4+5.4$ & $12.1+5.1$ \\
\hline $4^{\text {th }}$ & $\begin{array}{r}15.4+3 \\
5\end{array}$ & $25.9+5.4$ & $29.5+6.5$ & $21.15+4.0$ & $8.7+2.6$ & $10.8+4.9$ & $12.3+7.1$ & $7.1+4.2$ \\
\hline
\end{tabular}

Another clear trend could be detected from results in Table 5. Least-squares means for $E_{\mathrm{SCC}}$ within each class of stage of lactation tend to increase with progressing parity. As expected, older cows show usually higher $\mathrm{E}_{\mathrm{SCC}}$, as they become more and more susceptible to mastitis infection with advancing age. This result agrees with those reported by other workers concerning parity effect such as Schutz et al. (1995). Within the low somatic cell count group, the difference in $\mathrm{E}_{\mathrm{SCC}}$ between the last lactational quarter of year (10-12 mo) and the first lactational quarter of year (1-3 mo) was not affected markedly by parity, where only small differences could be detected. However, the corresponding differences in the high somatic cell count group reflect obviously parity effect, where the differences between the two classes increased markedly with advancing parity from the first to the fourth parity. This result may suggest the existence of parity-stage of lactation interaction on $\mathrm{E}_{\mathrm{SCC}}$, especially when dealing with cows suffering from high incidence of mastitis measured on high level of $\mathrm{E}_{\mathrm{SCC}}$ in milk. Within parity, TDM increased with progressing lactation from the first lactational quarter of year $(1-3 \mathrm{mo})$ till the third lactational quarter of year (7-9 mo) and decreased thereafter showing a curve-linear 
fashion. This trend was true for all parities within both groups of milk somatic cell level in milk. Within all classes of stage of lactation, cows of the $\mathrm{LE}_{\mathrm{SCC}}$ group produced markedly more TDM than the comparable cows of the $\mathrm{HE}_{\mathrm{SCC}}$. This reflects the depressive effect of the $\mathrm{HE}_{\mathrm{SCC}}$ on the milk produced through the probable infection with mastitis in herds characterized by a $\mathrm{HE}_{\mathrm{SCC}}$. These results are in close agreement with those reported by Rupp and Boichard (2000).

Changes of $E_{S C C}$ and TDM across different levels of SCC:

Changes in $\mathrm{E}_{\mathrm{SCC}}$ and TDM among different levels of SCC and relative changes to overall mean are presented in Table 6 . In general, TDM decreased with advancing

Table 6. Changes of expected somatic cell count $\left(\mathbf{E}_{\mathrm{SCC}}\right)$ and test-day milk yield (TDM) among different levels of somatic cell count relative to overall mean within different farms

\begin{tabular}{|c|c|c|c|c|c|c|c|}
\hline \multirow[t]{2}{*}{ Farm } & \multirow{2}{*}{$\begin{array}{c}\text { Range } \\
\text { SCC }^{* 10^{3}}\end{array}$} & \multicolumn{3}{|c|}{$\mathrm{E}_{\mathrm{SCC}} * 10^{3}$} & \multicolumn{3}{|c|}{ TDM } \\
\hline & & Average & Chg $^{1}$ & $\% \mathrm{Chg}^{2}$ & Average & Chg $^{1}$ & $\% \mathrm{Chg}^{2}$ \\
\hline Av Chg & $\begin{array}{c}<500 \\
>500-<1000 \\
>1000-<1500 \\
>1500\end{array}$ & $\begin{array}{c}1006 \\
342 \\
709 \\
1131 \\
1598\end{array}$ & $\begin{array}{l}367.00 \\
422.00 \\
467.00 \\
418.67 \\
\end{array}$ & $\begin{array}{c}34.00 \\
70.48 \\
112.43 \\
158.85\end{array}$ & $\begin{array}{c}17.53 \\
18.25 \\
17.33 \\
12.61 \\
6.23\end{array}$ & $\begin{array}{l}-0.92 \\
-4.72 \\
-6.38 \\
-4.01 \\
\end{array}$ & $\begin{array}{c}104.11 \\
98.86 \\
71.93 \\
35.54 \\
77.61 \\
\end{array}$ \\
\hline Av Chg & $\begin{array}{c}<500 \\
>500-<1000 \\
>1000-<1500 \\
>1500\end{array}$ & $\begin{array}{c}1001 \\
351 \\
709 \\
1216 \\
1713\end{array}$ & $\begin{array}{l}358.00 \\
507.00 \\
497.00 \\
454.00 \\
\end{array}$ & $\begin{array}{c}35.06 \\
70.83 \\
121.48 \\
171.13\end{array}$ & $\begin{array}{l}21.94 \\
32.61 \\
28.64 \\
21.34 \\
12.34\end{array}$ & $\begin{array}{l}-3.97 \\
-7.30 \\
-9.00 \\
-6.76 \\
\end{array}$ & $\begin{array}{c}148.63 \\
130.54 \\
97.27 \\
56.24\end{array}$ \\
\hline Av Chg & $\begin{array}{c}<500 \\
>500-<1000 \\
>1000-<1500 \\
>1500\end{array}$ & $\begin{array}{c}1194 \\
405 \\
851 \\
1398 \\
1961\end{array}$ & $\begin{array}{l}446.00 \\
547.00 \\
563.00 \\
518.67 \\
\end{array}$ & $\begin{array}{c}33.91 \\
71.26 \\
117.06 \\
164.20\end{array}$ & $\begin{array}{l}17.91 \\
22.15 \\
17.15 \\
18.24 \\
15.33\end{array}$ & $\begin{array}{l}-5.00 \\
1.09 \\
-2.91 \\
-2.27 \\
\end{array}$ & $\begin{array}{c}123.67 \\
95.76 \\
101.84 \\
85.59\end{array}$ \\
\hline Delta Misr2 & $\begin{array}{c}<500 \\
>500-<1000 \\
>1000-<1500 \\
>1500\end{array}$ & $\begin{array}{c}942 \\
215 \\
697 \\
1109 \\
1701\end{array}$ & $\begin{array}{l}482.00 \\
412.00 \\
592.00 \\
495.33 \\
\end{array}$ & $\begin{array}{c}22.82 \\
73.99 \\
117.73 \\
180.57\end{array}$ & $\begin{array}{l}17.51 \\
24.16 \\
18.26 \\
19.42 \\
12.09\end{array}$ & $\begin{array}{l}-5.90 \\
1.16 \\
-7.33 \\
-4.02 \\
\end{array}$ & $\begin{array}{c}137.98 \\
104.28 \\
110.91 \\
69.05\end{array}$ \\
\hline
\end{tabular}

Av Chg : Average change

$\mathrm{Chg}^{1}=$ differences among sequence classes within group. ie. $709-342=367$

$\mathrm{Chg}^{2}=$ overall mean : classes ratio

level of milk somatic cell concentration. The amount of overall expected phenotypic reduction in TDM ranged from 0.92 to $6.38 \mathrm{~kg} / \mathrm{day}$. While the average reduction in TDM among different farms ranged from 2.27 to $6.76 \mathrm{~kg} /$ day. The average corresponding overall increase in $\mathrm{E}_{\mathrm{SCC}}$ was 418,670 cells $/ \mathrm{ml}$ milk. $\mathrm{E}_{\mathrm{SCC}}$ among farms ranged from 351,000 to $1,713,000,405,000$ to $1,961,000$ and 215,000 to $1,701,000$ cells $/ \mathrm{ml} \mathrm{milk} \mathrm{for} \mathrm{Dunia} \mathrm{farm,} \mathrm{Delta} \mathrm{Misr} \mathrm{farm} \mathrm{number} \mathrm{1,} \mathrm{and} \mathrm{Delta} \mathrm{Misr} \mathrm{farm}$ number 2, respectively. The highest reduction in TDM was in Dunia farm that 
showed the highest mean of TDM (21.94 kg/day). Average increases in $\mathrm{E}_{\mathrm{SCC}}$ among different farms ranged from 454,000 to 518,670 cells/ml milk. Although Delta Misr farm number 1 and Delta Misr farm number 2 showed approximately the same TDM mean (17.9 vs. $17.5 \mathrm{~kg} /$ day), the reduction in this trait was halved in Delta Misr farm number 1 compared with Delta Misr farm number 2. This may reflect some differences in udder health management among both farms. In general, the highest increase in $\mathrm{E}_{\mathrm{SCC}}$ was corresponded to the lowest TDM reduction (Delta Misr farm number 1). Therefore, the increase of $E_{S C C}$ within Delta Misr farm number 1 could be mainly attributed to non-medical factors (non-mastitic cows).

\section{Prediction equations for somatic cell count:}

To predict SCC in milk three models were generated (Table 7). $\mathrm{PE}_{\mathrm{SCC}}{ }^{0}$ is the general model based on data of daily milk yield (DY), stage of lactation (Stg) and parity $(\mathrm{Pr}) . \mathrm{PE}_{\mathrm{SCC}}{ }^{\mathrm{Pr} 1}$ to $\mathrm{PE}_{\mathrm{SCC}}{ }^{\mathrm{Pr} 4}$ are models to predict SCC for each of the first four parities, based on daily milk yield and stage of lactation. $\mathrm{PE}_{\mathrm{SCC}}{ }^{\mathrm{Mol}}$ to $\mathrm{PE}_{\mathrm{SCC}}{ }^{\mathrm{Mo} 10}$ represented models to predict SCC across the first 10 months of lactation using daily milk yield only. Estimates of partial regression coefficients in different models have negative values. DY showed the highest partial regression coefficients in different equations. Expected reductions in SCC ranged from $-52,550$ to $-66,660$ cells $/ \mathrm{ml}$ milk for each one $\mathrm{kg}$ increase in daily milk yield. Accuracy of SCC prediction using $\mathrm{PE}_{\mathrm{SCC}}{ }^{\mathrm{Pr} 1}$ was above $80 \%$ (the highest estimate) and ranged from $74.3 \%$ to $82.3 \%$ across the first four parities. Contributions of stage of lactation in expected SCC were very low in comparison with the effect of DY in different models. Therefore, using suitable $\mathrm{PE}_{\mathrm{SCC}}$ depending on the available data, SCC could be predicted every day or at each milking without applying SCC test. This tool could also be used for monitoring the general udder health in very short time without additional effort and costs.

Table 7. Estimates of partial regression coefficients (b), (and their standard error), intercept for somatic cell count prediction

\begin{tabular}{|c|c|c|c|c|c|}
\hline & \multicolumn{5}{|c|}{ General and parity coefficients of prediction equations } \\
\hline & All data $\mathbf{P E}^{0}$ & PE $^{\text {Pr1 }}$ & $\mathbf{P E} \mathbf{E}^{\mathrm{Pr} 2}$ & $\mathbf{P E}^{\mathrm{Pr} 3}$ & $\mathbf{P E}^{\mathrm{Pr} 4}$ \\
\hline Intercept & $2119 \pm 1.48$ & $2185 \pm 1.09$ & $2102 \pm 2.70$ & $2037 \pm 5.82$ & $2132 \pm 2.72$ \\
\hline $\mathbf{b}_{\mathbf{D Y}}$ & $-59.94 \pm 0.09$ & $-64.49 \pm 2.17$ & $-59.71 \pm 6.12$ & $-56.05 \pm 2.22$ & $-61.55 \pm 0.13$ \\
\hline $\mathbf{b}_{\text {Stg }}$ & $-9.56+0.40$ & $-7.51+0.18$ & $-4.91 \pm 1.09$ & $-5.07 \pm 1.08$ & $-7.12 \pm 0.91$ \\
\hline $\mathbf{b}_{\mathbf{P r}}$ & $-19.43+2.07$ & & & & \\
\hline Accuracy & 84.8 & 81.4 & 78.4 & 74.3 & 82.3 \\
\hline \multicolumn{6}{|c|}{ Monthly (Mo) Coefficient prediction equations } \\
\hline & PE & $\mathbf{P E}^{\mathrm{M02}}$ & $\mathbf{P E}^{\mathrm{Mo3}}$ & $\mathbf{P E}^{\mathrm{M04}}$ & $\mathbf{P E}^{\mathrm{Mo5}}$ \\
\hline intercept & $2216+1.39$ & $2130+1.23$ & $2091+2.63$ & $2021 \pm 4.12$ & $1960+3.22$ \\
\hline $\mathbf{b}_{\mathrm{DY}}$ & $-66.66 \pm 0.11$ & $-60.75 \pm 0.74$ & $-58.97 \pm 2.07$ & $-55.11 \pm 1.14$ & $-52.55 \pm 0.19$ \\
\hline \multirow[t]{2}{*}{ Accuracy } & 61.3 & 63.3 & 67.4 & 64.9 & 64.6 \\
\hline & PE ${ }^{\text {Mo6 }}$ & $\mathbf{P E}^{\mathrm{Mo} 7}$ & PE $^{\mathrm{Mo8}}$ & PE $^{\text {Mo99 }}$ & PE $E^{M 010}$ \\
\hline intercept & $998 \pm 1.62$ & $998 \pm 2.04$ & $1149 \pm 4.32$ & $1201 \pm 3.63$ & $2166 \pm 4.11$ \\
\hline $\mathbf{b}_{\mathrm{DY}}$ & $-62.30 \pm 2.12$ & $-59.40 \pm 1.17$ & $-54.30 \pm 4.19$ & $-55.60 \pm 2.21$ & $-63.62 \pm 3.21$ \\
\hline Accuracy & 57.4 & 57.9 & 67.4 & 64.3 & 67.6 \\
\hline
\end{tabular}

PE: prediction equation, DY: Daily milk yield, Stg: stage of lactation, Pr: parity 


\section{REFERENCES}

Afifi, E. A., M. H. Khalil, and M. A. Salem, 1992. Evaluation of imported and locally-born Friesian cows raised in commercial farms in Egypt. I-Models and non-genetic effects. Egypt J. Anim. Prod., 29 :17-41.

Amin, A. A., 1998. Selection indexes for improving some productive and reproductive traits in dairy cattle. Ph. D. Thesis, Fac. Agric. Hungary. Godollo Uni.

Boldman, K. G., L. A. Kriese, L. D.Van Vleck, C.P. Van Tassell, and S.D. Kachman, 1997. A Manual for Use of MTDFREML. A set of programs to obtain estimates of variances and co-variances. U.S. Department of Agric., Agric. Res. Service.

Barillet, F.; R. Rupp, S. M. Grasteav, J. M. Astruc, and M. Jacquin, 1984. Genetic analysis for mastitis resistance and milk SCS in French dairy cattle. Genet. Sel. Evol., 28: 169-181.

Emanuelson, U. and J. Philipsson,1984. Studies on somatic cell counts in milk of Swedish dairy cows. II. Estimation of genetic parameters for monthly test-day results. Acta Agri. Scand., 34:45-53.

Farghaly, H. M., 2002. Comparison among different mathematical models of lactation curves to describe the somatic cell counts in Fleckvieh milk. Zagazig J. Agric. Res., 29: 211-228.

Gary, H., 1985. Standard methods for the examination of dairy products. $15^{\text {th }}$ Edition. American Public Health Association. Washington, D. C. pp 246-248.

Liebe, A.; H. Worstorff, and D. Schams, 1996. Changes in somatic cell count and plasma cortisol concentration during three relocation trials in German Brown cows. Milchwissenschaft 51:423-426.

Miller, R. H., 1984. Traits for Sire Selection Related to Udder Health and Management. J. Dairy Sci., 67:459-471.

Mohamed, S. E., 1998. Inheritance of somatic cell count and its genetic relationship with productive traits in dairy cattle. M. Sc. Thesis, Fac. Agric. Zagazig Univ. Zagazig, Egypt.

Mrode, R. A. and C.J.T. Swanson, 1996. Genetic and statistical properties of somatic cell count and its suitability as an indirect means of reducing the incidence of mastitis in dairy cattle. Anim. Breeding Abst. 64 : 847-857.

Rodriguez, S Zas; D. Gianola, and GE. Shook, 2000. Evaluation of models for somatic cell score lactation patterns in Holsteins. J. Livestock Prod. Sci., 67:1930.

Roger, B. and Peter, E., 1995. Mastitis control in dairy herds an illustrated and practical guide. $1^{\text {st }}$ Edition. Farming Press Publications, United Kingdom.

Rogers, G. W.; G.L. Hargrove, T.J. JR Lawlor, and J.L. Ebersole, 1991. Correlations among linear type traits and somatic cell counts. J. Dairy Sci., 74: 1087-1091.

Rupp, R. and D. Boichard, 2000. Relationship of early first lactation somatic cell count with risk of subsequent first clinical mastitis. J. Livestock Prod. Sci., 62:169-180. 
Schutz, M. M.; P.M. Van Radein, and G.R. Wiggans, 1994. Genetic variation in lactation means of somatic cell scores for six breeds of dairy cattle. J. Dairy Sci., 77: 284-293.

Schutz, M. M.; P.M. Van Radein, G.R. Wiggans, and H.D. Norman, 1995. Standardization of lactation means of somatic cell scores for lactation of genetic evaluations. J. Dairy Sci.,78: 1843-1854.

Soliman, A. M. and M.A. Khalil, 1993. Estimation of genetic parameters for single and composite milk trait in Fleckvieh cattle and their uses in programmers of early selection. Egypt. J. Anim. Prod., 30: 21-37.

Zhang. W. C; J.C.M. Dekkers, G. Banos, and E.B. Burnside, 1994. Adjustment factors and genetic evaluation for somatic cell score and relationships with other traits of Canadian Holsteins. J. Dairy Sci., 77: 659-665. 
بعض العوامل المؤثرة على التركيز المرئى للخلايا الجسدية في اللبن وإنتاج اللبن لعينة يوم

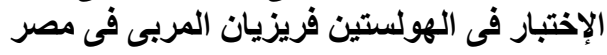

سمير مختار ، أشرف أمين ، عبد الله غازى

قسم الإنتاج الحيوانى ، كلية النراعة، جامعة قناة السويس، الإسعاعيلية، مصر

درس تأثير بعض العوامل لتقدير العلاقة بين إنتاج لبن (عينة يوم الإختبار) وتركيز الخلايا

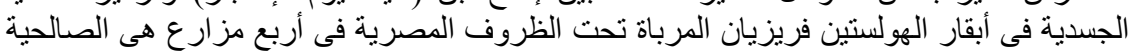

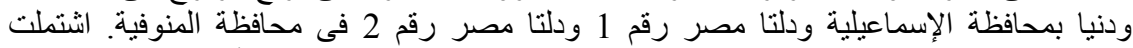

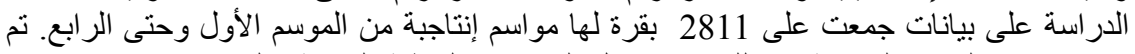

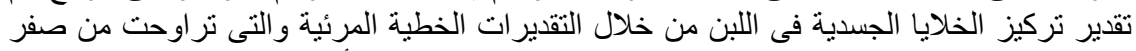

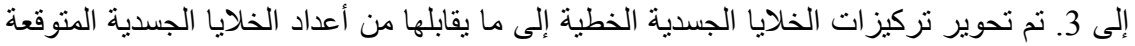

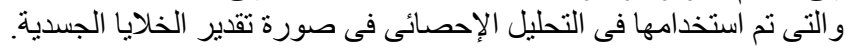

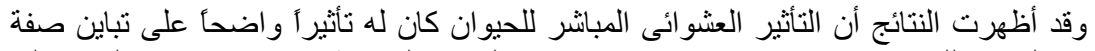

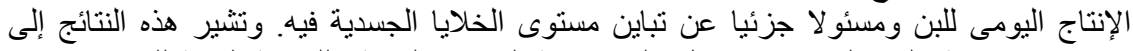

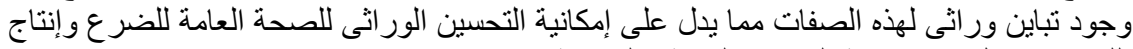

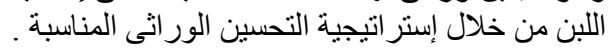

تراوحت المتوسطات العامة لإنتاج اللبن وعدد الخلايا الجسدية المتوقعة فى يوم الاختبار بين

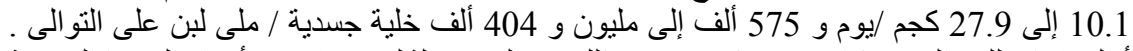

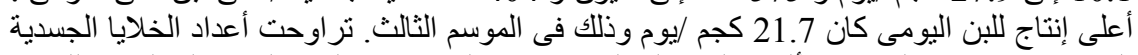

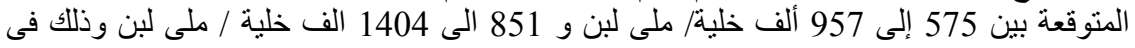
مجمو عتى الخلايا الجسدية المنخفضة و المرتفعة على التو الىى.

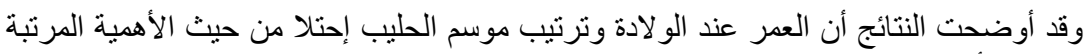

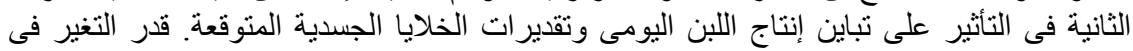

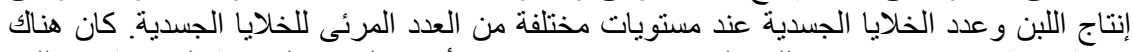

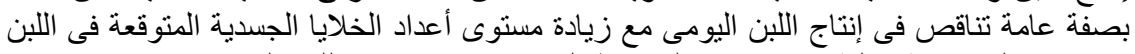

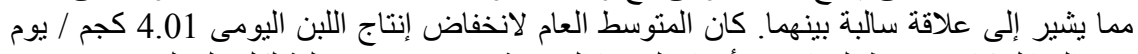

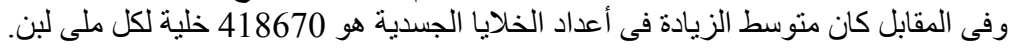




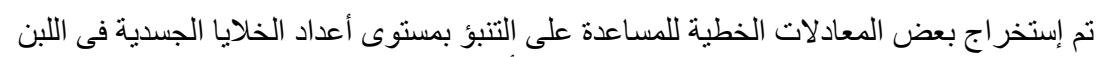

باستخدام بعض المعلومات مثل إنتاج اللبن اليومى، عدد أيام الحليب ، ترتيب موسم الحليب. و المعادلة الئلة الئل

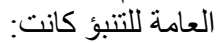

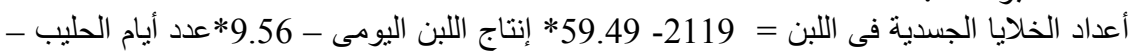

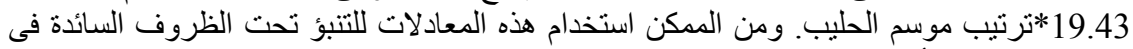
المز ارع المحلية لأبقار الهولستين فريزيان وفد تراوحت دقة التتبؤ باستخدام هذه المعادلة بين 57.4 
